\title{
Penitipan Anak Yang Berkonflik Dengan Hukum Di Balai Perlindungan Rehabilitasi Remaja Daerah Sleman
}

\author{
Ulfah Rahmah Wati \\ Magister Hukum Fakultas Hukum Universitas Islam Indonesia Yogyakarta Indonesia \\ Jln. Cik Di Tiro No. 1 Yogyakarta Indonesia \\ ulfahrahma0@gmail.com
}

\begin{abstract}
This study aims to discuss about children in conflict with the law entrusted to the Youth Social Protection and Rehabilitation Center. The current conflicting child care practice is still not optimal in handling child care cases. The legal materials used are primary legal materials and secondary legal materials collected through news of events from the Sleman Police, the Child Public Prosecutor from the Sleman District Attorney, Juvenile Judges from the Sleman District Court, and Social Workers from the Youth Protection and Rehabilitation Center and supported by literature studies. The analysis was carried out with a qualitative method. The juridical-sociological approach is seen from a legal point of view related to juvenile delinquency. The conclusions of this study are: first, the function of the BPRSR is to rehabilitate and also serve as a place of detention if there is no LPAS because BPRSR is appointed as LPKS; second, care and detention are the same, because in practice such care limits the child's movement space and robs the child of independence; third, the status of children in conflict with the law as a deposit is a factor in not reducing the criminal sanctions that will be received by the child.
\end{abstract}

Key Words: Child delinquency; criminal sanctions; day care

\begin{abstract}
Abstrak
Studi ini bertujuan untuk membahas mengenai anak yang berkonflik dengan hukum dititipkan pada Balai Perlindungan dan Rehabilitasi Sosial Remaja. Praktik penitipan anak yang berkonflik saat ini masih belum maksimal dalam menangani kasus penitipan anak. Bahan hukum yang digunakan yaitu bahan hukum primer dan bahan hukum sekunder yang dikumpulkan melalui berita peristiwa dari Polres Sleman, Penuntut Umum Anak dari Kejaksaan Negeri Sleman, Hakim Anak dari Pengadilan Negeri Sleman, dan Pekerja Sosial dari Balai Perlindungan dan Rehabilitasi Remaja serta didukung dengan studi kepustakaan. Analisis dilakukan dengan metode kualitatif. Pendekatan dengan yuridissosiologis dilihat dari sudut pandang hukum terkait kenakalan anak. Kesimpulan dari penelitian ini adalah: pertama, fungsi dari BPRSR adalah untuk merehabilitasi dan juga sebagai tempat penahanan jika tidak terdapat LPAS karena BPRSR ditunjuk sebagai LPKS; kedua, penitipan dan penahanan sama, karena pada praktiknya penitipan tersebut membatasi ruang gerak anak dan merampas kemerdekaan anak; ketiga, status anak yang berkonflik dengan hukum sebagai titipan merupakan faktor tidak dikuranginya sanksi pidana yang akan diterima anak.
\end{abstract}

Kata-kata Kunci: Kenakalan anak; penitipan; sanksi pidana 


\section{Pendahuluan}

Anak marupakan permulaan sebelum menjadi orang dewasa, oleh karena itu setiap tingkah laku anak membutuhkan banyak perhatian karena anak yang emosinya belum stabil mudah untuk dipengaruhi oleh lingkungan. ${ }^{1}$ Tingkah laku anak pada umumnya belum stabil tersebut, belum memahami mengenai baik atau buruk dan benar atau salah. Sehingga dalam tumbuh kembang anak dalam hal tingkah laku anak perlu adanya pembelajaran baik dari dalam dirinya maupun lingkungan yang berada sekitarnya. ${ }^{2}$ Anak yang juga merupakan subyek hukum akan mendapatkan hak dan kewajibannya yang sama serta kasih sayang, karena setiap anak berhak untuk mendapatkan kesejahteraan hidup baik sekarang pada masa pertumbuhannya maupun di masa depannya. Hal tersebut tercantum di dalam Pasal 2 Undang-Undang Nomor 4 Tahun 1979 tentang Kesejahteraan Anak, yang memuat tentang hak dan perlindungan untuk terciptanya kesejahteraan anak. Jika setiap anak memperoleh kesejahteraan hidup yang sesuai dengan umurnya, maka bukan suatu hal yang tidak mungkin dapat mengurangi jumlah anak nakal atau kenakalan anak.

Pada praktiknya, pelaku tindak pidana ternyata tidak hanya terbatas dilakukan oleh orang dewasa saja, tetapi juga dilakukan oleh anak-anak yang dalam hal ini termasuk dalam kenakalan anak. Tindakan-tindakan yang tidak terkontrol dan terarah menyebabkan perilaku menyimpang berupa kenakalan anak yang melawan hukum sehingga harus ada pertanggungjawaban atas tindakannya di hadapan hukum. Kenakalan anak sering disebut dengan "juvenile delinquency" yang artinya anak cacat sosial. ${ }^{3}$ Menurut Moeljatno, bahwa dalam Pasal 44 KUHP menjelaskan adanya kemampuan bertanggung jawab harus ada kemampuan untuk dapat membedakan antara perbuatan baik dan perbuatan yang buruk, sesuai dengan hukum atau melawan hukum, dan kemampuan untuk menentukan kehendaknya menurut keinsyafan tentang baik dan buruknya perbuatan tersebut. 4

Pertanggungjawaban yang diberikan kepada anak memiliki kekhususan. Hal tersebut terdapat di dalam Undang-Undang Nomor 11 Tahun 2012 tentang Sistem Peradilan Anak. Dalam sistem peradilan anak, baik aparat penegak hukum hingga pada aparat dan/atau pekerja sosial dalam penerapan

${ }^{1}$ M. Nasir Djamil, Anak. Bukan untuk Dibukum, Sinar Grafika, Jakarta, 2013, hlm. 46.

2 Abintoro Prakoso, Pembaruan Sistem Perdilan Pidana Anak, Aswaja Pressindo, Yogyakarta, 2016, hlm. 38.

${ }^{3}$ Maidin Gultom, Perlindungan Hukum Terbadap Anak dalam Sistem Peradilan Anak di Indonesia, PT Refika Aditam, Bandung, 2008, hlm. 55.

Marlina, Peradilan Pidana Anak di Indonesia Pengembangan Konsep Diversi dan Restorative Justice, PT Refika Aditama, Bandung, 2009, hlm. 70, sebagaimana dikutip dari Moeljatno, Asas-Asas Hukum Pidana, Cetakan Kedua, Bina Aksara, Jakarta, 1984, hlm. 172-173. 
putusannya, bahwa setiap anak yang berhadapan dengan hukum menggunakan acara pidana anak termasuk dalam penahanannya. Karena dalam praktiknya sering kali anak yang melakukan tindak pidana diperlakukan sama dengan orang dewasa yang juga melakukan tindak pidana. Sehingga anak yang berhadapan dengan hukum tersebut tidak mendapatkan perlindungan yang sesuai dengan usianya dalam menjalani proses penyidikan oleh penyidik sampai pada penjatuhan putusan hakim.

Orang dewasa pada proses penyidikan akan ditahan, tidak hanya dalam tahap penyidikan pada proses pembuktian atau persidangan juga akan ditahan oleh penuntut umum atau hakim. Akan tetapi seorang anak tidak diperbolehkan dilakukan penahanan, jika mendapat jaminan dari orang tua dan/atau wali, lembaga yang dapat menjamin anak tidak akan melarikan diri, menghilangkan dan/atau menghancurkan barang bukti serta dapat menjamin anak tidak akan mengulangi tindak pidana. Hal tersebut sesuai dengan Pasal 32 ayat (1) UndangUndang Nomor 11 Tahun 2012 tentang Sistem Peradilan Anak yang menyatakan bahwa setiap anak berhak untuk tidak ditangkap atau ditahan, kecuali merupakan suatu upaya akhir. Jika dengan terpaksa anak harus dilakukan penangkapan dan atau penahanan, anak tersebut harus memenuhi syarat. Syarat tersebut tertuang di dalam Undang-Undang Nomor 11 Tahun 2012 yaitu anak tersebut telah berumur 14 tahun atau lebih dan juga diduga melakukan tindak pidana dengan ancaman pidana penjara 7 tahun atau lebih.

Anak dalam hal melakukan tindak pidana setelah dilakukan penangkapan harus ditempatkan di ruangan khusus atau disebut dengan Ruang Pelayanan Khusus (RPK) di kantor kepolisian. Dengan adanya hal tersebut maka setiap kantor polisi harus memiliki ruangan khusus anak. Adapun dalam penahanan oleh penuntut umum dan hakim, harus dibedakan tempat penahanannya dari orang dewasa, jika tidak memiliki atau tidak memadai maka dititipkan pada LPAS. Tetapi jika tidak ada LPAS maka dapat ditempatkan di Lembaga Penyelenggaraan Kesejahteraan Sosial (LPKS).

Kasus yang terjadi di daerah hukum Pengadilan Negeri Sleman terdapat beberapa Anak yang dititipkan di BPRSR (Balai Perlindungan dan Rehabilitasi Sosial Remaja) dengan aturan bahwa anak tidak dibebaskan keluar dari wilayah BPRSR. Jika anak yang berhadapan dengan hukum tersebut akan keluar dari wilayah BPRSR maka harus dengan izin dari penyidik, penuntut umum atau hakim yang melakukan penitipan pada anak tersebut. Anak yang berhadapan dengan yang dititipkan juga tidak bersekolah seperti pada umumnya. Akan tetapi anak tetap mendapatkan pendidikan yang diberikan dari BPRSR. Jika dilihat dari praktiknya, penitipan yang dilakukan hampir sama dengan penahanan. Kedua 
hal tersebut yaitu dengan tidak dibebaskan anak untuk keluar dari wilayah BPRSR dan tidak mendapatkan pendidikan seperti pada umumnya memiliki kesamaan yaitu membatasi kemerdekaan seseorang. ${ }^{5}$

Fakta di lapangan, anak yang berhadapan dengan hukum dititipkan di BPRSR dengan tidak diperbolehkan keluar dari wilayah BPRSR, dengan kurun waktu yang tidak ditentukan. Banyak anak yang dititipkan di balai tersebut lebih dari 6 bulan akibat dari proses peradilannya yang tidak segera mendapatkan keputusan. ${ }^{6}$ Akan tetapi, pada saat keputusan pengadilan telah ditetapkan, masa penitipan yang sama secara praktik sama dengan penahanan yang berada di BPRSR tidak mengurangi masa pemidanaan. Sedangkan dalam Pasal 22 ayat (4) KUHAP telah ditegaskan bahwa masa penangkapan dan/atau penahanan yang telah dilakukan terhadapnya dikurangkan seluruhnya dari pidana yang dijatuhkan.

Menjadi suatu masalah baru ketika das sein tidak sejalan dengan das sollen. Dari praktik penahanan dengan cara anak yang berhadapan dengan hukum dititipkan di Balai Perlindungan dan Rehabilitasi Sosial Remaja tersebut tidak sesuai dengan yang tercantum dalam Pasal 22 ayat (4) KUHAP dan melanggar hak-hak anak baik anak pada umumnya atau anak yang berhadapan dengan hukum.

\section{Rumusan Masalah}

Berdasarkan penjelasan pada latar belakang di atas, dapat dirumuskan rumusan masalah sebagai berikut: pertama, apa fungsi dari Balai Perlindungan dan Rehabilitasi Sosial Remaja? Kedua, apakah penitipan di Balai Perlindungan dan Rehabilitasi Sosial Remaja (BPRSR) sama dengan penahanan? Ketiga, apakah penitipan yang dilakukan di Balai Perlindungan dan Rehabilitasi Sosial Remaja (BPRSR) tersebut dapat mengurangi sanksi pidana yang akan dijalani?

\section{Tujuan Penelitian}

Adapaun tujuan dari penulisan ini adalah untuk mengetahui dan memahami: pertama, fungsi dari Balai Perlindungan dan Rehabilitasi Sosial Remaja atau BPRSR; Kedua, persamaan antara penahanan dengan penitipan yang dilakukan Balai Perlindungan dan Rehabilitasi Sosial Remaja (BPRSR); dan Ketiga, adanya pengurangan atau tidak dari penitipan yang dilakukan di Balai Perlindungan dan Rehabilitasi Sosial Remaja.

\footnotetext{
5 Gede Made Swardhana, Pengendalian Kenakalan Anak Berbasis Kearifan Lokal Masyarakat Bali, Genta Publishing, Yogyakarta, 2016, hlm. 72.

${ }^{6}$ R. Wiyono, Sistem Peradilan Pidana Anak di Indonesia, Sinar Grafika, Jakarta Timur, 2016, hlm. 27.
} 


\section{Metode Penelitian}

Penelitian dibutuhkan sebuah metode untuk mendapatkan informasi yang diinginkan. Metode yang digunakan dalam tulisan ini adalah normatif empiris. Aturan yang digunakan dalam penulisan ini adalah Undang-Undang Dasar Republik Indonesia tahun 1945 sebagai acuan pokok dengan dilengkapi KUHP (Kitab Undang-Undang Hukum Pidana), KUHAP (Kitab Undang-Undang Hukum Acara Pidana), Undang-Undang No. 11 Tahun 2012 tentang Sistem Peradilan Anak, Undang-Undang Nomor 35 Tahun 2015 tentang Perubahan Atas Undang-Undang Nomor 23 Tahun 2002 tentang Perlindungan Anak, UndangUndang Nomor 4 Tahun 1979 tentang Kesejahteraan Anak.

Metode empiris yang digunakan membutuhkan suatu subyek penelitian. Pada penulisan ini, subyek penelitian adalah Unit Pelayanan Perempuan dan Anak (PPA) di Polres Sleman, Jaksa pada Kejaksaan Negeri Sleman, Hakim pada Pengadilan Negeri Sleman, Pekerja sosial di Balai Perlindungan dan Rehabilitasi Sosial Remaja di Sleman. ${ }^{7}$ Pengumpulan data dari subyek penelitian tersebut dilakukan dengan wawancara, yaitu mengajukan pertanyaan secara langsung kepada subyek penelitian.

\section{Hasil Penelitian dan Pembahasan}

\section{Fungsi Balai Perlindungan dan Rehabilitasi Sosial Remaja}

Balai Perlindungan dan Rehabilitasi Sosial Remaja adalah balai yang dalam pengawasan oleh Dinas Sosial dan berfungsi: ${ }^{8}$

a) penyusunan program kerja Balai;

b) penyusunan pedoman teknis pelayanan perlindungan, rehabilitasi, advokasi sosial, reunifikasi dan rujukan;

c) penyebarluasan informasi dan sosialisasi pelaksanaan pemetaan masalah kesejahteraan sosial remaja bermasalah sosial dan anak yang berhadapan dengan hukum;

d) pelaksanaan identifikasi dan pemetaan pelayanan perlindungan dan rehabilitasi sosial penyandang masalah kesejahteraan sosial remaja terlantar bermasalah sosial dan anak yang berhadapan dengan hukum;

e) fasilitasi pendampingan, mediasi pelaku dan korban anak yang berhadapan dengan hukum;

f) penyelenggaraan dan pengembangan pelayanan perlindungan, rehabilitasi, advokasi sosial, reunifikasi dan rujukan remaja bermasalah sosial dan anak yang berhadapan dengan hukum;

${ }^{7}$ Ulfah Rahmah Wati, Praktik Penitipan Anak yang Berkonflik dengan Hukum di Balai Perlindungan dan Rehabilitasi Sosial Remaja (Studi Kasus di Daerah Hukum Pengadilan Sleman), Skripsi, Program Sarjana Universitas Islam Indonesia, Yogyakarta, 2018, hlm. 6.

${ }^{8}$ http://dinsos.jogjaprov.go.id/balai-prsr/,diakses pada 18 Agustus 2021 pukul 17.28 WIB. 
g) penyelenggaraan jejaring penanganan remaja bermasalah sosial dan anak yang berhadapan dengan hukum;

h) fasilitasi, pelayanan, rehabilitasi, advokasi sosial dan reunifikasi bagi anak yang berhadapan dengan hukum berbasis keluarga;

i) fasilitasi penelitian dan pengembangan kesejahteraan sosial untuk pelayanan perlindungan dan rehabilitasi sosial remaja bermasalah sosial dan anak yang berhadapan dengan hukum;

j) pelaksanaan ketatausahaan; dan

k) pelaksanaan monitoring, evaluasi dan penyusunan laporan program Balai.

Fungsi BPRSR tersebut disebutkan bahwa anak yang menjadi objek. Tujuan pokok dari BPRSR adalah perlindungan rehabilitasi sosial remaja bermasalah sosial dan anak yang berhadapan dengan hukum $(\mathrm{ABH}) .{ }^{9}$ Dari fungsi dan tujuan pokok tersebut, dapat dilihat bahwa Balai Perlindungan dan Rehabilitasi Sosial Remaja adalah tempat yang diperuntukkan untuk anak, termasuk anak yang berhadapan dengan hukum.

Seseorang dapat dikatakan sebagai anak apabila berusia maksimal 18 tahun, kecuali yang ditegaskan di dalam Undang-Undang Nomor 4 Tahun 1979 tentang Kesejahteraan Anak dimana mengatur mengenai batasan anak sampai dengan berumur 21 tahun. Indonesia mengenal salah satu asas yaitu asas equality before the law atau disebut dengan persamaan di depan hukum, yang mengajarkan bahwa tidak ada perbedaan menurut hukum untuk menjatuhkan suatu sanksi pidana bagi pelaku tindak pidana. Namun, akan ada perbedaan apabila pelaku tindak pidana tersebut orang dewasa dan anak-anak. Tidak hanya mengenai segi usia saja, perbedaan antara orang dewasa dan anak-anak dilihat dari segi perundang-undangannya maupun sistem peradilan pidana yang sesuai dengan subyek hukum. Perbedaan tersebut dapat dilihat dalam Undang-Undang Nomor 35 Tahun 2014 tentang Perubahan atas Undang-Undang Nomor 23 Tahun 2002 tentang Perlindungan Anak yang disebutkan bahwa anak berbeda dengan orang dewasa, baik secara umur, fisik, maupun mental. Hal ini ditunjukkan dan tertuang dalam undang-undang tersebut bahwa anak tidak dapat disamakan dengan orang dewasa. Pasal demi pasal di dalam UndangUndang Kesejahteraan Anak, telah mengupayakan segala sesuatu yang berkaitan dengan anak adalah untuk kepentingan dan kesejahteraan anak itu sendiri.

Perbedaan orang dewasa dengan anak-anak juga terlihat dari segi hukum yang ada di Indonesia. Anak memiliki peraturan sendiri dalam beracara di peradilan, hal ini dilihat dari segi adanya peraturan perundang-undangannya yang telah dibentuk oleh pemerintah yaitu Undang-Undang Nomor 11 Tahun

\footnotetext{
${ }^{9}$ Ulfah Rahmah Wati, Praktik Penitipan..., Op. Cit., hlm. 40.
} 
2012 tentang Sistem Peradilan Pidana Anak. Dengan dibentuknya aturan tersebut, pemerintah telah berusaha untuk menjaga kepentingan tumbuh dan kembang anak. Tidak hanya mengenai UU SPPA akan tetapi pemerintah juga telah berupaya untuk mensejahterakan anak tanpa membedakan antara anak yang satu dengan anak yang lainnya. Tidak membeda-bedakan dalam artian bahwa antara anak yang melakukan tindak pidana dengan anak yang tidak melakukan tindak pidana tetap sama di mata hukum, mereka tetaplah anak-anak.

Upaya yang dilakukan oleh pemerintah khususnya yaitu pemerintah daerah Yogyakarta untuk membedakan antara anak-anak dengan orang dewasa yang melakukan suatu bentuk tindak pidana dapat terlihat dari tempat penahanannya. Orang dewasa yang diduga melakukan tindak pidana maupun yang telah diputus bersalah melakukan suatu tindak pidana, ditahan di Lembaga Pemasyarakatan (LAPAS), sedangkan untuk anak ditahan di LAPAS Anak yang bertempat di Gunung Kidul. Akan tetapi LAPAS Anak yang berada di Gunung Kidul tersebut saat ini telah melebihi kapasitas. Selain di LAPAS Anak, anak juga dapat ditahan di Lembaga Permasyarakatan Anak yang berada di Wonosari. Untuk kasus yang ada di Kabupaten Sleman, jika anak ditahan di Lembaga Permasyarakatan Anak Wonosari terlalu jauh karena jarak tempuh dari Wonosari sampai ke Sleman khususnya Pengadilan Negeri Sleman memakan waktu kurang lebih dua jam. ${ }^{10}$ Hal tersebut dirasa kurang efektif dari segi jarak dan waktu, karena dengan adanya anak yang berkonflik dengan hukum jika di tempatkan di LAPAS Anak Wonosari maka akan memperlambat proses pemeriksaan. Sehingga tidak adanya tempat untuk penahanan yang dekat dengan Pengadilan Negeri Sleman, maka anak yang berhadapan dengan hukum maupun anak yang berkonflik dengan hukum dititipkan di Balai Perlindungan dan Rehabilitasi Sosial Remaja karena tidak memungkinkan juga untuk melakukan penahanan bersama orang dewasa. ${ }^{11}$

Undang-Undang SPPA telah mengatur bahwa dalam hal anak dilakukan penahanan, dapat dilakukan di LPAS. Apabila LPAS tidak ada di daerah tersebut maka penahanan dapat dititipkan di LPKS. Surat Kementrian Sosial No. 44 Tahun 2015, BPRSR yang ada di Sleman ditunjuk sebagai LPKS sejak 2015. Dengan penunjukkan tersebut, BPRSR dapat menjadi tempat untuk dilakukan penahanan sementara. Akan tetapi, penegak hukum yang ada di Sleman mengatakan bahwa penitipan yang ada di BPRSR bukan merupakan penahanan. ${ }^{12} \mathrm{Hal}$ tersebut tidak sesuai undang-undang dan juga fungsi BPRSR.

\footnotetext{
${ }^{10}$ Hasil wawancara dengan Wiwik, Jaksa Anak, di Sleman, pada 30 Januari 2018.

11 Ibid.

12 Ulfah Rahmah Wati, Praktik Penitipan..., Op. Cit., hlm. 56
} 


\section{Persamaan antara Penahanan dan Penitipan yang Dilakukan Balai Perlindungan dan Rehabilitasi Sosial Remaja (BPRSR)}

Anak yang berkonflik dengan hukum diperlakukan secara sama di hadapan pengadilan karena anak tersebut tetap dianggap sebagai anak pada umumnya. Hal ini dapat dilihat dari sistem peradilan pidana anak, karena beracara pada peradilan anak aparat penegak hukum merupakan aparat yang telah ditunjuk oleh lembaganya untuk menangani kasus anak. Sehingga anak dapat diperlakukan sesuai dengan usia serta hak-hak yang seharusnya diperoleh. Hal ini menunjukkan bahwa terdapat kesesuaian antara peraturan perundangundangan dengan praktiknya. Anak yang diduga telah melakukan tindak pidana atau yang disebut dengan anak yang berkonflik dengan hukum pada proses pemeriksaan di pengadilan menggunakan peraturan mengenai anak yaitu menggunakan Undang-Undang Nomor 11 Tahun 2012 tentang Sistem Peradilan Pidana Anak. Undang-undang tersebut telah mengatur mengenai proses pemeriksaan termasuk penahanan. Menurut Andi Hamzah dalam bukunya, yang dimaksud dengan penahanan adalah suatu bentuk perampasan kemerdekaan. ${ }^{13}$ Penahanan terhadap anak pada hakekatnya adalah membatasi sementara fisik seorang anak. ${ }^{14}$ Sesuai dengan peraturan, penahanan merupakan kepentingan pemeriksaan. Akan tetapi pada kasus anak, penahanan anak diharuskan untuk memperhatikan kepentingan anak itu sendiri dengan memperhatikan baik secara fisik, mental, sosial maupun kepentingan masyarakat. Akan tetapi penahanan terhadap anak tersebut dapat dilakukan jika merupakan suatu upaya terakhir yang dapat dilakukan oleh aparat penegak hukum.

Pada kasus yang berada di daerah hukum Pengadilan Sleman, anak tidak dilakukan penahanan akan tetapi dengan istilah dititipkan ke Balai Perlindungan dan Rehabilitasi Sosial Remaja (BPRSR). ${ }^{15}$ Pengertian dari penitipan tidak ada dalam peraturan maupun dalam undang-undang. Berdasarkan hasil penelitian, penitipan yang dilakukan oleh penyidik, penuntut umum, maupun hakim anak, penitipan dan penahanan yang dilakukan di BPRSR tersebut dapat dimaknai sebagai sesuatu hal yang sama. Karena praktiknya anak yang berkonflik dengan hukum di Kabupaten Sleman tidak dapat dengan bebas keluar dari balai. Anak hanya boleh ke luar dengan batasan di wilayah balai saja. ${ }^{16}$ Seorang anak keluar dari wilayah balai diperbolehkan dengan persyaratan bahwa anak tersebut mendapat izin sesuai dengan statusnya, jika sedang dalam

13 Andi Hamzah, Hukum Acara Pidana Indonesia, Sinar Grafika, Jakarta, 2014, hlm. 129.

${ }^{14}$ Rusli Muhammad, Hukum Acara Pidana Kontemporer, PT Citra Aditya Bakti, Yogyakarta, 2007, hlm. 63.

${ }^{15}$ Hasil wawancara dengan Eko Mei Purwanto, Kepala Unit Pelayanan Perempuan dan Anak dan Wiwik Triatmini, Jaksa Anak, di Sleman, pada 30 Januari 2018.

${ }^{16}$ Hasil wawancara dengan Bapak Sutoyo, Ketua BPRSR, di Sleman, pada 1 Februari 2018. 
proses penyidikan maka harus mendapat izin dari penyidik anak, jika dalam proses penuntutan harus mendapat izin dari penuntut umum, serta jika dalam proses pemeriksaan di pengadilan maka harus mendapat izin dari hakim anak.17

Dalam hal anak mendapatkan izin, anak yang akan keluar dari BPRSR harus diantar dan dijemput oleh orang tua atau wali dengan membuat surat pernyataan bahwa anak tersebut akan didampingi oleh orang tua atau wali selama keluar dari wilayah BPRSR. Izin yang akan dimintakan juga tidak bisa sewaktu-waktu diajukan, ada waktu-waktu tertentu yang diberikan baik dari pihak balai maupun penitip (penyidik, penuntut umum, atau hakim). Hal ini menunjukkan adanya pembatasan fisik dan juga ruang gerak terhadap anak yang berkonflik dengan hukum yang dititipkan di BPRSR. Dari praktik penitipan yang dilakukan tersebut antara penitipan dan penahanan tidak terdapat perbedaan. Ada unsur perampasan kemerdekaan yaitu tidak ada kebebasan bergerak terhadap anak yang ditipkan di BPRSR. Jika hal tersebut dimaknai sebagai penitipan, tidak ada perampasaan kemerdekaan serta bukanlah penahanan seharusnya anak dibebaskan untuk keluar dari wilayah BPRSR, anak juga dapat bertemu dengan orang tua dan keluarganya sewaktu-waktu, serta anak dapat bersekolah dimana ia bersekolah sebelumnya tanpa harus menggunakan izin dan mendapati pengawasan khusus. ${ }^{18}$

Undang-Undang Nomor 11 Tahun 2012 tentang Sistem Peradilan Anak mengatur bahwa anak tidak diperbolehkan ditahan untuk anak yang dalam hal ini orang tua atau walinya dapat menjamin bahwa anak tersebut tidak akan melarikan diri dan/atau merusak barang bukti maupun dapat menjamin bahwa anak tidak mengulangi tindak pidana lagi. Jika akan dilakukan penahanan, maka anak tersebut harus berumur 14 tahun atau lebih dan melakukan tindak pidana dengan ancaman pidana tujuh tahun hukuman penjara atau lebih.

\section{Pengurangan Sanksi Pidana yang akan Dijalani atas Penitipan yang Dilakukan di Balai Perlindungan dan Rehabilitasi Sosial Remaja (BPRSR)}

Selama proses persidangan, penuntut umum telah mencantumkan dalam surat dakwaan bahwa tidak dilakukan penahanan tetapi dititipkan di BPRSR. Akan tetapi di dalam surat tuntutan tidak berisikan mengenai pengurangan tuntutan pidana atas penitipan yang dilakukan di BPRSR. Dari hasil penelitian, penuntut umum selama ini jarang atau hampir tidak pernah meminta kepada pihak balai bahwa anak telah menjalani penitipan. Jika penuntut umum meminta surat keterangan bahwa anak dilakukan penitipan dari pihak balai, maka surat 
tersebut dapat dijadikan sebagai pengurangan sanksi pidana yang akan dijalani kemudian hari. ${ }^{19}$

Tahap pembuktian, hakim tidak secara langsung menitipkan anak pada BPRSR. Karena dalam hal tidak ada tempat untuk anak di Sleman, hakim lebih memilih untuk menitipkan anak pada Polres Sleman dan hakim tidak mengetahui anak tersebut dititipkan dimana oleh Polres Sleman. ${ }^{20}$ Dari hasil wawancara, Polres Sleman menitipkannya tetap pada BPRSR. Sehingga lamanya anak di balai tersebut tetap tidak bisa dipastikan, karena harus menunggu hingga proses pemeriksaan sampai dengan dikeluarkan keputusan oleh pengadilan. Setelah adanya putusan yang menyatakan anak tidak bersalah, maka anak akan keluar dari balai. Sedangkan jika anak dinyatakan bersalah, dan dijatuhi hukuman pidana serta denda maka denda tersebut digantikan dengan pelatihan kerja di BPRSR. Pelatihan kerja dijalani apabila sudah menjalani hukuman pidana penjara telah selesai. ${ }^{21}$

Menurut Christina Endarwati selaku hakim anak di Pengadilan Negeri Sleman, anak yang dititipkan pada BPRSR tidak mengurangi masa pemidanaan yang akan dijalani. Karena status dari anak adalah penitipan bukan penahanan. Akan tetapi menurut keterangannya jika pada saat pelimpahan berkas ke pengadilan terdapat surat yang menyatakan anak tersebut telah menjalani rehabilitasi dan dititipkan di BPRSR maka hal tersebut akan mengurangi masa pemidanaan yang akan dijalani anak. ${ }^{22}$ Dari hasil wawancara yang diperoleh dari hakim anak di Pengadilan Negeri Sleman, pengurangan terhadap lamanya anak menjalani penitipan di BPRSR tergantung dari penyidik maupun penuntut umum yang melampirkan surat penitipan anak di BPRSR atau tidaknya. Akan tetapi pada fakta di lapangan, hakim mengetahui bahwa anak dititipkan di balai tersebut. Sehingga ada atau tidaknya surat pernyataan tersebut, hakim seharusnya berusaha untuk menegakkan keadilan bagi anak dengan cara mengurangi masa lamanya penitipan yang telah dilakukan anak di BPRSR untuk masa tahanan yang akan dijatuhkan dan dijalani anak kemudian hari atau dengan cara meminta penyidik maupun penuntut umum untuk meminta surat keterangan dari BPRSR.

Berdasarkan penelitian, penitipan yang dilakukan di BPRSR tidak diatur dalam undang-undang. Penitipan tersebut dilakukan karena tidak ada tempat untuk penahanan di Sleman. Penitipan ini menjadi dilema bagi aparat penegak hukum, karena jika tidak dititipkan masyarakat akan menilai buruk, baik

\footnotetext{
${ }^{19}$ Hasil wawancara dengan Ibu Christina, Hakim Anak, di Sleman, 21 Februari 2018.

${ }^{20}$ Hasil wawancara dengan Ibu Christina, Hakim Anak, di Sleman, pada 21 Februari 2018.

${ }^{21}$ Ibid.

${ }^{22}$ Ibid.
} 
terhadap aparat penegak hukum maupun terhadap anak itu sendiri. Tetapi jika dititipkan, status dari anak juga menjadi kabur. Kabur yang dimaksudkan yaitu status anak bukanlah tahanan karena tidak ditahan secara materiil, meskipun pada praktiknya penitipan yang dilakukan sama dengan penahanan. Kasus yang terjadi di Kabupaten Sleman tersebut merupakan implementasi dari tidak adanya kepastian hukum untuk menangani kasus anak yang berkonflik dengan hukum yang terjadi di Kabupaten Sleman.

BPRSR adalah balai yang di bawahi oleh Dinas Sosial DIY dan BPRSR ditunjuk sebagai LPKS, sesuai dengan Pasal 32 ayat (5) dan Pasal 33 ayat (5) Undang-Undang Nomor 11 Tahun 2012 tentang Sistem Peradilan Pidana Anak bahwa anak dapat dilakukan penahanan di LPKS (Lembaga Penyelenggara Kesejahteraan Sosial) jika tidak terdapat LPAS (Lembaga Penempatan Anak Sementara). Maka anak yang berkonflik dengan hukum yang dititipkan di BPRSR dapat dikatakan bahwa anak tersebut ditahan. Karena pada dasarnya BPRSR adalah LPKS maka status dititipkan seharusnya dapat menjadi ditahan. Sehingga anak yang berkonflik dengan hukum di BPRSR, mendapat pengurangan masa pemidanaan karena telah menjalani penahanan yang berada di BPRSR. Hal ini tidak menimbulkan dilema bagi aparat penegak hukum maupun bagi anak, karena status anak menjadi jelas ketika menjalani penitipan di BPRSR. Dengan adanya status yang jelas yaitu ditahan di BPRSR maka anak akan mendapat pengurangan masa penahanan karena dapat dikeluarkan surat penangguhan penahanan. Jika status anak adalah titipan, tidak semua penyidik anak maupun penuntut umum anak yang memintakan surat pernyataan dari Balai yang menerangkan anak dititipkan karena sedang menjalani proses pemeriksaan. Sehingga tidak ada yang menjadi dasar untuk mengurangi masa pemidanaan yang akan dijalani anak yang berkonflik dengan hukum pada saat akan dikeluarkan keputusan dari Pengadilan Negeri Sleman.

Pada praktikya, anak yang berkonflik dengan hukum telah dititipkan yang pengertian penitipan sama dengan penahanan di Balai Perlindungan dan Rehabilitasi Sosial Remaja (BPRSR) tetapi pada saat penjatuhan putusan, tidak ada pengurangan masa pemidanaan yang akan dijalani.

\section{Penutup}

Berdasarkan pembahasan di atas, disimpulkan: pertama, Balai Perlindungan dan Rehabilitasi Sosial Remaja ditunjuk sebagai LPKS oleh Kementrian Sosial Republik Indonesia sejak 2015 dengan Surat Kementrian Sosial No. 44 Tahun 2015. Fungsi dari (BPRSR) selain untuk merehabilitasi anak-anak yang mengalami masalah sosial, juga sebagai tempat untuk merehabilitasi anak yang berhadapan 
dengan hukum. Sesuai dengan Surat Kementrian Sosial tersebut, anak yang berkonflik dengan hukum dapat dilakukan penahanan di BPRSR karena tidak ada LPAS di wilayah Kabupaten Sleman. Kedua, penitipan di Balai Perlindungan dan Rehabilitasi Sosial Remaja oleh penegak hukum di Sleman, mempunyai pengertian yang sama dengan penahanan jika dilihat dari praktik yang merampasan kemerdekaan serta membatasi ruang gerak anak. Selain itu, balai tersebut dapat menjadi tempat untuk penahanan sementara anak yang berkonflik dengan hukum karena tidak adanya LPAS. Oleh karena itu penitipan yang dilakukan tersebut merupakan penahanan. Ketiga, status anak yang berkonflik dengan hukum selama dititipkan di BPRSR menjadi faktor utama untuk tidak dikuranginya masa pemidanaan pada saat dikeluarkan penjatuhan pidana. Karena Anak yang statusnya dititipkan di BPRSR, maka tidak dapat dilakukan penangguhan penahanan. Akan tetapi jika penegak hukum memahami pentingnya keadilan, penegak hukum akan selalu berupaya penitipan yang dilakukan di BPRSR untuk dapat mengurangi pemidanaan yang akan dijatuhkan dan dijalani oleh anak.

\section{Daftar Pustaka}

\section{Buku}

Djamil, M. Nasir, Anak Bukan untuk Dihukum, Sinar Grafika, Jakarta, 2013.

Gultom, Maidin, Perlindungan Hukum Terhadap Anak dalam Sistem Peradilan Anak di Indonesia, PT Refika Aditam, Bandung, 2008.

Hadisuprapto, Paulus, Juvenile Delinquency Pemahaman dan Penanggulangannya, PT. Citra Aditya Bakti, Bandung, 1997.

Hamzah, Andi, Hukum Acara Pidana Indonesia, Sinar Grafika, Jakarta, 2014.

Marlina, Peradilan Pidana Anak di Indonesia Pengembangan Konsep Diversi dan Restorative Justice, PT Refika Aditama, Bandung, 2009.

Muhammad, Rusli, Hukum Acara Pidana Kontemporer, PT Citra Aditya Bakti, Yogyakarta.

Mulyadi, Lilik, Wajah Sistem Peradilan Pidana Anak Indonesia, Bandung: PT Alumni, 2014.

Nashriana, Perlindungan Hukum Pidana bagi Anak di Indonesia, PT RajaGrafindo Persada, Jakarta, 2011.

Prakoso, Abintoro, Pembaruan Sistem Perdilan Pidana Anak, Aswaja Pressindo, Yogyakarta, 2016.

R. Wiyono, Sistem Peradilan Pidana Anak di Indonesia, Sinar Grafika, Jakarta Timur, 2016.

Sofyan, Andi dan Abd Asis, Hukum Acara Pidana Suatu Pengantar, Prenadamedia Group, Jakarta, 2014. 
Swardhana, Gede Made, Pengendalian Kenakalan Anak Berbasis Kearifan Lokal Masyarakat Bali, Genta Publishing, Yogyakarta, 2016.

\section{Hasil Penelitian/Tugas Akhir}

Ulfah Rahmah Wati, Praktik Penitipan Anak yang Berkonflik dengan Hukum di Balai Perlindungan dan Rehabilitasi Sosial Remaja (Studi Kasus di Daerah Hukum Pengadilan Sleman, Skripsi, Program Sarjana Universitas Islam Indonesia, Yogyakarta, 2018

\section{Hasil Wawancara}

Hasil wawancara dengan Bapak Eko Mei Purwanto, Kepala Unit Pelayanan Perempuan dan Anak, di Sleman, pada 30 Januari 2018.

Hasil wawancara dengan Ibu Wiwik Triatmini, Jaksa Anak, di Sleman, pada 30 Januari 2018.

Hasil wawancara dengan Bapak Sutoyo, Ketua BPRSR, di Sleman, pada 1 Februari 2018.

Hasil wawancara dengan Ibu Christina, Hakim Anak, di Sleman, pada 21 Februari 2018.

Hasil wawancara dengan Ibu Wiwik, Jaksa Anak, di Sleman, pada 30 Januari 2018.

\section{Internet}

http://dinsos.jogjaprov.go.id/balai-prsr/, diakses pada 18 Agustus 2021 pukul 17.28 WIB.

\section{Peraturan Perundang-Undangan}

Undang-Undang Dasar Republik Indonesia Tahun 1945.

Kitab Undang-Undang Hukum Pidana.

Kitab Undang-Undang Hukum Acara Pidana.

Undang-Undang Nomor 4 Tahun 1979 tentang Kesejahteraan Anak.

Undang-Undang Nomor 35 Tahun 2015 tentang Perubahan Atas Undang-Undang Nomor 23 Tahun 2002 tentang Perlindungan Anak.

Undang-Undang Nomor 11 Tahun 2012 tentang Sistem Peradilan Anak.

Surat Keputusan Menteri Sosial Republik Indonesia Nomor 44/Huk/2015 tentang Lembaga Penyelenggaraan Kesejahteraan Sosial Sebagai Pelaksana Rehabilitasi Sosial Anak Yang Berhadapan Dengan Hukum. 